CZASOPISMO INŻYNIERII LA¿DOWEJ, ŚRODOWISKA I ARCHITEKTURY

JOURNAL OF CIVIL ENGINEERING, ENVIRONMENT AND ARCHITECTURE

JCEEA, t. XXXIV, z. 64 (3/II/17), lipiec-wrzesień 2017, s. 125-136, DOI:10.7862/rb.2017.159

Maciej KAPOŁKA ${ }^{1}$

\title{
PLANY REGULACJI PRZESTRZENNEJ POLSKICH WIELKICH MIAST W PIERWSZEJ POLOWIE XX WIEKU A WSPÓŁCZESNE KONCEPCJE ROZWOJU OŚRODKÓW MIEJSKICH W POLSCE
}

\begin{abstract}
Choć korzenie koncepcji tzw. polskich Wielkich Miast sięgają XIX wieku, to ich realizacja i największy rozmach, z którym systematycznie starano się wprowadzać je w życie przypada na pierwszą połowę wieku XX. Uformowanie II Rzeczpospolitej, po odzyskaniu przez Polskę niepodległości w 1918 r., stało się momentem przełomowym dla lokalnej planistyki, a nowa sytuacja polityczna była doskonałą okazją dla aparatu administracyjnego, do popularyzacji koncepcji planistycznych i systematycznego ich realizowania. Wzorem przeprowadzonego w 1909 r. konkursu na projekt regulacji Wielkiego Krakowa (determinującego kształt miasta w okresie międzywojennym) i opracowanego na jego podstawie planu regulacyjnego, zaczęto formułować analogiczne koncepcje dla innych miast, niekiedy także na podstawie prestiżowych konkursów architektonicznych. Wspomnieć należy w tym kontekście chociażby ogłoszony 15 Marca 1921 r. konkurs na plan rozbudowy i przebudowy Lwowa, czy rozpisany w 1930 r. konkurs na projekt regulacji i zabudowy miasta Poznania. Zabiegi te posiadały nie tylko wartość planistyczną, ale także zauważalny aspekt polityczny i społeczny. Autor opisuje poszczególne koncepcje oraz niektóre, interesujące prace konkursowe, z uwzględnieniem warunków w jakich zostały opracowane oraz tła, na którym idee te były formułowane. Zaobserwowane analogie pomiędzy koncepcjami historycznymi i współczesnymi zostały wypunktowane i przeanalizowano źródła ich zaistnienia. Zwrócono także uwagę na różnice w planowaniu przestrzennym z pierwszej połowy XX wieku i we współczesnym podejściu do zbliżonej problematyki. Wzięto pod uwagę miasta należące do ziem polskich współcześnie oraz w poruszanym okresie historycznym.
\end{abstract}

Słowa kluczowe: Wielki Kraków, Wielka Warszawa, Projekt regulacji i zabudowy Poznania, Plan regulacyjny, Dwudziestolecie Międzywojenne, Planowanie przestrzenne

${ }^{1}$ Maciej Kapołka, doktorant, Politechnika Krakowska, ul. Podchorążych 28/6, 30-009 Kraków; tel.: 609475 960; e-mail: maciekkapolka@gmail.com 


\section{Wprowadzenie}

Jak zauważył w 1928 roku, we wstępie do rozważań na temat planu regulacyjnego Warszawy, Stanisław Różański, „Plany regulacyjne miast wogóle, a miast wielkich w szczególności wymagają długotrwałych i wszechstronnych wysiłków mózgów specjalistów. Paryż, Berlin, Londyn, Wiedeń dziesiątkami lat przy pomocy często potężnych środków finansowych pracowały metodycznie, a mimo to zarówno urzeczywistnione idee, jak i plany regulacyjne nie są w całości racjonalne."2. Myśl ta, choć nie do końca optymistyczna, jest w pełni uzasadniona. Szczególnie w kontekście przemian politycznych i społecznych, zachodzących na terenach Polski w pierwszych latach XX wieku, oraz w świetle dynamicznej sytuacji w Europie i na terenie kraju w latach późniejszych.

Rosnące aspiracje władz miejskich i mieszkańców większych ośrodków doprowadziły do systematycznego dążenia do powiększenia granic miast. Chętnie podejmowano działania, mające na celu usankcjonowanie, usystematyzowanie i efektywne implementowanie założeń politycznych w sferę urbanistyczną i częściowo architektoniczną. Naturalnym następstwem tych wielkomiejskich dążeń wydaje się opracowanie szeregu planów regulacyjnych, w założeniu zapewniających właściwe kierunki rozwoju, na nowo definiowanych miast. Wyjątkowo interesujące są przypadki opracowania wspomnianych planów na podstawie konkursów architektonicznych. Postępowania takie, poza najbardziej znanym konkursem krakowskim (rys. 1.), przeprowadzono chociażby na terenie Kalisza (I nagrodę otrzymała praca autorstwa Tadeusza Zielińskiego i Zygmunta Wóycickiego) ${ }^{3}$ i Poznania (I nagrodę otrzymała praca autorstwa Stanisława Filipkowskiego i Jana Graeffe $)^{4}$.

Sięgająca XIX wieku tendencja do niekontrolowanego koncentrycznego i promieniowego ${ }^{5}$ narastania tkanki miejskiej miała zostać opanowana. Rozwój miast miał odbywać się w sposób zrównoważony i kontrolowany. W ostatnim czasie, w części ośrodków objętych w ubiegłym wieku szeregiem planów regulacyjnych, zaobserwować można nawrót do niekontrolowanego i nieodpowiedniego wypełniania istniejących struktur miejskich, oraz chaotycznego rozwoju w strefie oddziaływania miasta.

\footnotetext{
2 [12], s. 41, pisownia oryginalna.

3 [8], s. 27.

${ }^{4}$ [4], s. 107.

${ }^{5}$ [15], s. 56-59.
} 


\section{Wybrane plany regulacyjne miast polskich $\mathrm{z}$ pierwszej połowy XX wieku - krótka charakterystyka}

\subsection{Plan Wielkiego Krakowa}

Plan Wielkiego Krakowa jest prawdopodobnie jednym z najbardziej znanych planów regulacyjnych w historii polskiej urbanistyki. Nie ulega jednak wątpliwości, że zarówno sama koncepcja, długotrwały proces poszerzania granic najgęściej zaludnionego miasta monarchii habsburskiej ${ }^{6}$, prowadzący do wytworzenia znacznego organizmu miejskiego, jak i ogłoszony w 1909 roku konkurs na projekt planu regulacyjnego Wielkiego Krakowa były w historii polskiej planistyki wyjątkowo ważnymi wydarzeniami.

W dużej mierze jest to zasługa ówczesnego prezydenta Krakowa, Juliusza $\mathrm{Leo}^{7}$, wyraźnie zabiegającego o powiększenie granic miasta i pod którego kierownictwem rozpoczęto prace nad tym, bardzo ambitnym, zadaniem. W związku z prowadzonymi działaniami w 1905 roku, sporządzono „Plan położenia siedemnastu gmin okalających Kraków”, które brane były pod uwagę w kontekście rozwoju miasta ${ }^{8}$.

Zarządy gmin podmiejskich zapraszane były do pertraktacji, prowadzących w większości przypadków do przychylnego rozpatrzenia propozycji przyłączenia do miasta. Problematyczne okazały się Podgórze, Płaszów, Krowodrza oraz Grzegórzki, przy czym dwie pierwsze w znacznym stopniu sprzeciwiały się włączeniu do miasta. Ostatecznie włączenie Podgórza do Krakowa w $1915^{9}$ roku przypieczętowało realizację idei prezydenta Leo, a powierzchnia miasta wzrosła do 48,54 km², powiększając się niemal siedmiokrotnie ${ }^{10}$.

Ogłoszony w kwietniu 1909 roku konkurs na „Plan regulacji Wielkiego Krakowa" wyznaczył podstawowe kierunki, o jakich myśleć należało w kontekście rozwoju miasta. Jak ujęli to autorzy oficjalnych warunków konkursowych: „Zadanie niniejsze ma przedstawić rozszerzenie istniejącego miasta na przyległe gminy sąsiednie, przy zastosowaniu najnowszych wymagań ruchu komunikacyjnego - zdrowia publicznego, estetyki i gospodarstwa miejskiego." ${ }^{11} \mathrm{Na}$ postępowanie nadesłano 9 prac, z czego 6 gmina zdecydowała się zakupić. Po służyły one de facto za punkt wyjściowy dla sformułowania właściwych wytycz-

\footnotetext{
${ }^{6}[3]$, s. 5.

7 Juliusz Leo pierwszy wniosek dotyczący przyłączenia pobliskich gmin zgłosił na posiedzeniu miejskiej komisji do sprawy budowy kanału wodnego Wisła - Dunaj oraz portu rzecznego w Krakowie w dniu 6 lutego 1902 roku. Komisja mianowała wnioskodawcę referentem do spraw rozszerzenia granic miasta. W tym okresie (lata 1901-1904) Juliusz Leo pełnił urząd wiceprezydenta Krakowa.

${ }^{8}$ [3], s. 22.

${ }^{9}$ Decyzja o połączeniu Podgórza z Krakowem została ogłoszona 1 lipca 1915 roku. Symbolem zjednoczenia stało się spotkanie prezydentów miast na moście Krakusa.

10 [7], s. 49.

${ }^{11}$ [16], s. 88, pisownia oryginalna.
} 
nych dla rozwoju miasta. Do dziś zauważalnym efektem działań projektantów jest, wytyczona na trasie przebiegu dawnej kolei obwodowej, oś tzw. Alei Trzech Wieszczów ${ }^{12}$, oraz wyznaczone na przebiegu nieistniejących murów miejskich Planty. ${ }^{13}$

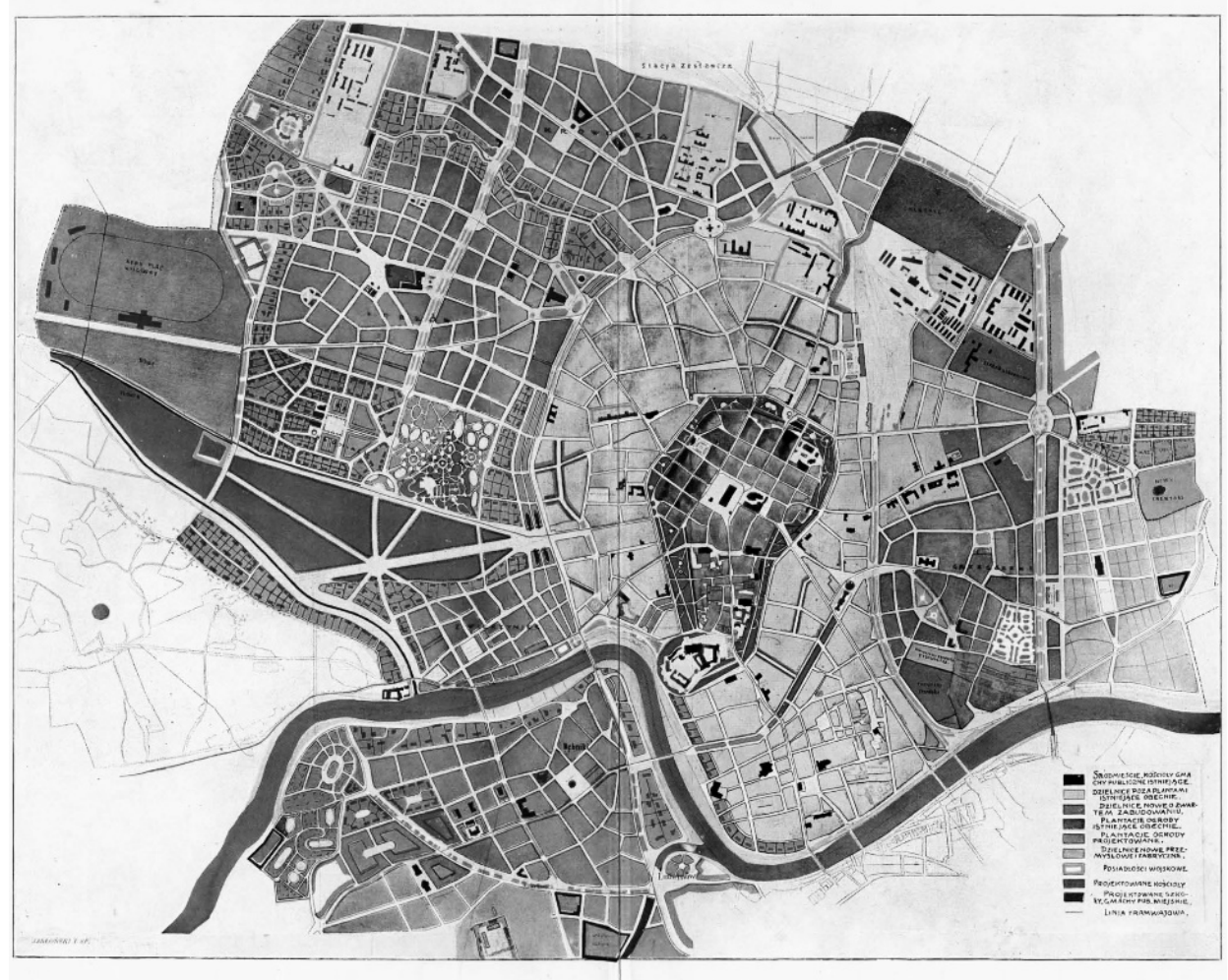

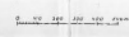

Rys. 1. Zwycięski projekt konkursowy autorstwa Józefa Czajowskiego, Władysława Ekielskiego, Tadeusza Stryjeńskiego, Ludwika Wojtyczki i Kazimierza Wyczyńskiego. Reprodukcję opublikowano w formie niezależnej tablicy w czasopiśmie „Architekt”, nr 6, 1910

Fig. 1. The design that was awarded the first prize in the competition for the Greater Kraków Regulatory Plan, prepared by Władysław Ekielski, Tadeusz Stryjeński, Ludwik Wojtyczko and Kazimierz Wyczyński. The reproduction was published in the magazine „Architekt”, nr 6, 1910

12 [2], s. 62-63, Nazwa zwyczajowa, do osi należą kolejno: al. Mickiewicza, al. Słowackiego, al. Krasińskiego.

${ }^{13}[14]$ 


\subsection{Wielki Poznań}

Stycznia 1925 roku „Wielkopolanin ilustrowany” poinformował opinię publiczną, że 1 stycznia, w myśl rozporządzenia Rady Ministrów z 17 grudnia 1924 roku, do Poznania przyłączono szereg gmin przyległych ${ }^{14}$, a powierzchnia ośrodka wzrosła niemal dwukrotnie, z 3405 do 6736 ha $^{15}$. Poznań doczekał się też kompleksowego opracowania planistycznego. „Plan ogólny zabudowania miasta Poznania", opracowany został w 1929 roku przez Sylwestra Pajzderskiego $^{16}$. Nie był to jednak pierwszy projekt, opierający się na poszerzeniu granic miasta. Ponad ćwierć wieku wcześniej, niemiecki urbanista Josef H. Stübben ${ }^{17}$ wykonał plan strefowy, także uwzględniający podmiejskie gminy i wsi, a katalizatorem dla jego stworzenia była decyzja o zniesieniu wewnętrznego pierścienia pruskiej twierdzy, uniemożliwiającej płynny rozwój centrum miejskiego.

Wspomniany plan Pajzderskiego spotkał się jednak z krytyką Władysława Czarneckiego, prowadzoną w Kole Architektów, a efektem tego działania stało się rozpisanie w 1930 roku konkursu na projekt regulacyjny miasta. ${ }^{18}$ Wedle programu „Celem konkursu jest uzyskanie szeregu rozwiązań i pomysłów, które posłużyłyby za podstawę do opracowania definitywnego planu regulacji miasta i skierowały rozwój jego na właściwe tory, odpowiadające współczesnym wymaganiom budowy miast"19. W warunkach podkreślono ponadto, że zakres opracowania wynika z zaproponowanych granic Wielkiego Poznania ${ }^{20}$.

Praca która otrzymała pierwszą nagrodę (rys. 2) została doceniona za racjonalność rozwiązań komunikacyjnych i odpowiedniej formie i skali zieleni dla ówczesnej „nowoczesnej koncepcji wielkiego miasta”. Wedle jury konkursowego „Komunikacja kolei i lotnicza pomyślana dobrze. Dobre rozwiązanie dworca centralnego, wraz z „,ity”21, nadające się do zrealizowania”. ${ }^{22}$

Po rozstrzygnięciu konkursu, zgromadzony materiał został wykorzystany w trakcie prac, kierowanych przez Władysława Czarneckiego (odpowiedzialnego, przecież w dużej mierze za przeprowadzenie postępowania oraz uczestniczącego w obradach jury) Pracowni Urbanistycznej. Zespół oparł swoje działania na bardzo aktualnych wciąż metodach, polegając między innymi na omówieniu aktualnych teorii urbanistycznych, czy na europejskich opracowaniach dotyczących czynników takich jak demografia, kształtowanie zieleni i środowiska, polityka mieszkaniowa, segregacja ruchu, czy zintegrowany system komunikacji

\footnotetext{
${ }^{14}$ Gminy: Dębiec, Główna, Komandoria, Rataje ,Mała Starołęka, Winiary i Naramowice.

15 [4], s. 105.

16 [9], opublikowano drukiem.

17 [5]

18 [4], s. 106, konkurs na „Projekt regulacji i zabudowy miasta Poznania”.

${ }_{19}$ za: [10], s. 2, pisownia oryginalna.

${ }^{20}[10]$, s. 2.

${ }^{21}$ Szczególnie interesujący zwrot, wywodzący się z historii urbanistyki Londynu.

${ }^{22}$ za [2], s. 5.
} 
miejskiej. Ponadto w trakcie prac nad planem ogólnym Poznania, w latach 19301937 Czarnecki odbył studialną podróż po Europie i uczestniczył w wydarzeniach, takich jak II Ogólnopolska Konferencja Urbanistyczna, międzynarodowy kongres architektów w Pradze, V Kongres CIAM, czy Międzynarodowa Wystawa Sztuki i Techniki w Paryżu W efekcie wstępne plany, opracowane przez zespół Czarneckiego zawierały kompletny zestaw studialny, odzwierciedlający dość precyzyjnie potrzeby ówczesnego miasta ${ }^{23}$, o stopniu wnikliwości odpowiadającemu współczesnej myśli urbanistycznej ${ }^{24}$.

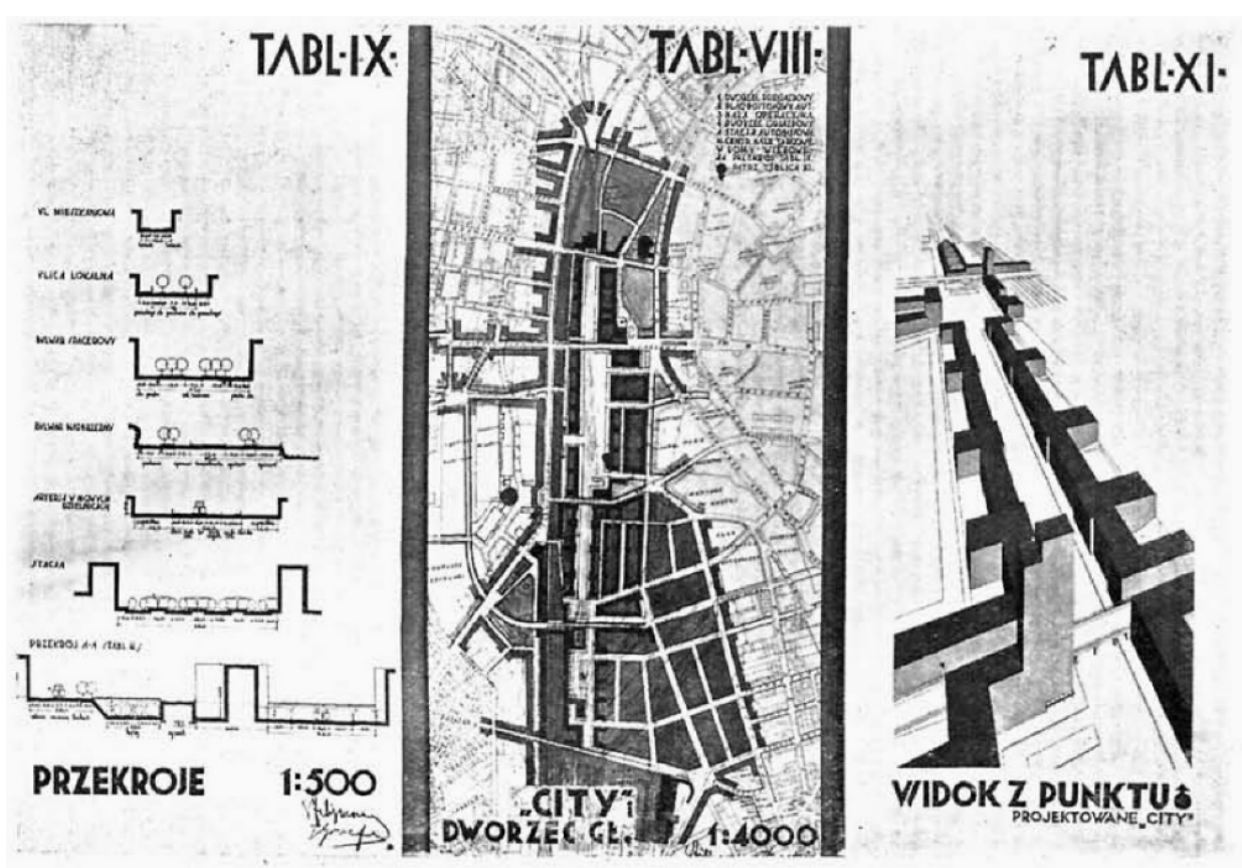

1-3. Arch.: Stanislaw Filipkowski i Jan Graeffe (Warszawa). Praca konkursowa Nr. 4, na projekt regulacji i zabudowy $m$. Poznania. Nagroda $I$.

Rys. 2. Rysunki pochodzące ze zwycięskiej pracy na Projekt regulacji i zabudowy miasta Poznania. Reprodukcję opublikowano w czasopiśmie „Architektura i Budownictwo”, nr 1, 1932, s. 1

Fig. 2. Drawings from the work, awarded with the 1 st prize in the competition for the regulation and development plan of Poznań. The reproduction was published in the magazine „Architektura i Budownictwo", nr 1, 1932, p. 1

\footnotetext{
23 [4], s. $111-113$

${ }^{24}$ Plansze planu ogólnego nie zachowały się do dnia dzisiejszego.
} 


\subsection{Regulacja Warszawy}

W ostatnim czasie poszerzenie granic Warszawy stał się jednym z najczęściej poruszanych kwestii politycznych związanych z polską urbanistyką. Powrót idei Wielkiej Warszawy wrócił, wprawdzie w zupełnie innej sytuacji społecznej, gospodarczej i terytorialnej, niż pierwotny, miał także służyć (już w założeniu) zupełnie innym celom, ale w pewien sposób wzbudzić mógł zainteresowanie historyczną koncepcją i powiązanymi z nią zjawiskami.

Wiek XIX dla warszawskiej urbanistyki nie był okresem wyjątkowo korzystnym. Ogólny plan regulacyjny nie istniał, realizowane były, natomiast mniejsze projekty cząstkowe ${ }^{25}$. Jak zauważył Czesław Rudnicki w opublikowanym na łamach numeru czasopisma „Architektura i Budownictwa”, poświęconemu historii regulacji Warszawy, „Nie ulega wątpliwości, że działalność regulacyjna rozwinęłaby się w Warszawie bardzo pomyślnie, gdyby nie ciężkie warunki, w jakich się znajdowała (...). Istotnie, w okresach względnego spokoju zjawiały się usiłowania do racjonalnego załatwienia sprawy regulacji i zabudowania miasta" 26 .

Momentem przełomowym dla warszawskiej urbanistyki okazał się wybuch I wojny światowej i związane z jej trwaniem i zakończeniem efekty polityczne. Pierwszym dokumentem tego typu, utworzonym w owym okresie był utworzony przez Koło Architektów wstępny plan regulacyjny (pod kierownictwem Tadeusza Tołwińskiego) ${ }^{27}$, obejmujący obszar przyłączonych w 1915 roku terenów. Stanowił on później jedną z podstaw dla opracowania właściwej koncepcji rozwojowej miasta. Następnie w 1917 roku utworzono Biuro do spraw regulacji i zabudowania miasta, które opracowało plany: własnościowy i wysokościowy, zbierające podstawowe informacje na temat ewidencji gruntów oraz budynków (w tym także dane o terenowych potrzebach instytucji państwowych). W trakcie prac uporządkowano także wiele nieścisłości w zastanych dokumentacjach $\mathrm{i}$ innych dokumentach, powiązanych $\mathrm{z}$ architektoniczną tkanką miasta.

Zebrane dane pozwoliły ostatecznie na sformułowanie przez wspomniane biuro w latach 1920-1923 trzech opracowań: planu regulacyjnego ${ }^{28}$, szkicowego planu zabudowania strefowego ${ }^{29}$ i nowego, poprawionego planu ${ }^{30}$ regulacyjnego, stanowiącego podstawę dla projektów szczegółowych.

\footnotetext{
25 [13] s. 404, mowa między innymi o przywołanych w tekście źródłowym: przebitej w 1822 roku szerokiej alei Jerozolimskiej, usprawnienie komunikacji, sieci ulic na południe od al. Jerozolimskiej i na zachód od ul. Marszałkowskiej, połączeniu placu Zamkowego z ul. Dobrą.

26 [13] s. 404-405.

27 [8], s. 26-27, Plan powstał jako „Szkic wstępny planu regulacyjnego Warszawy”, obejmował obszar blisko 8000 ha.

${ }^{28} 1920$ rok.

291922 rok.

${ }^{30} 1923$ rok.
} 


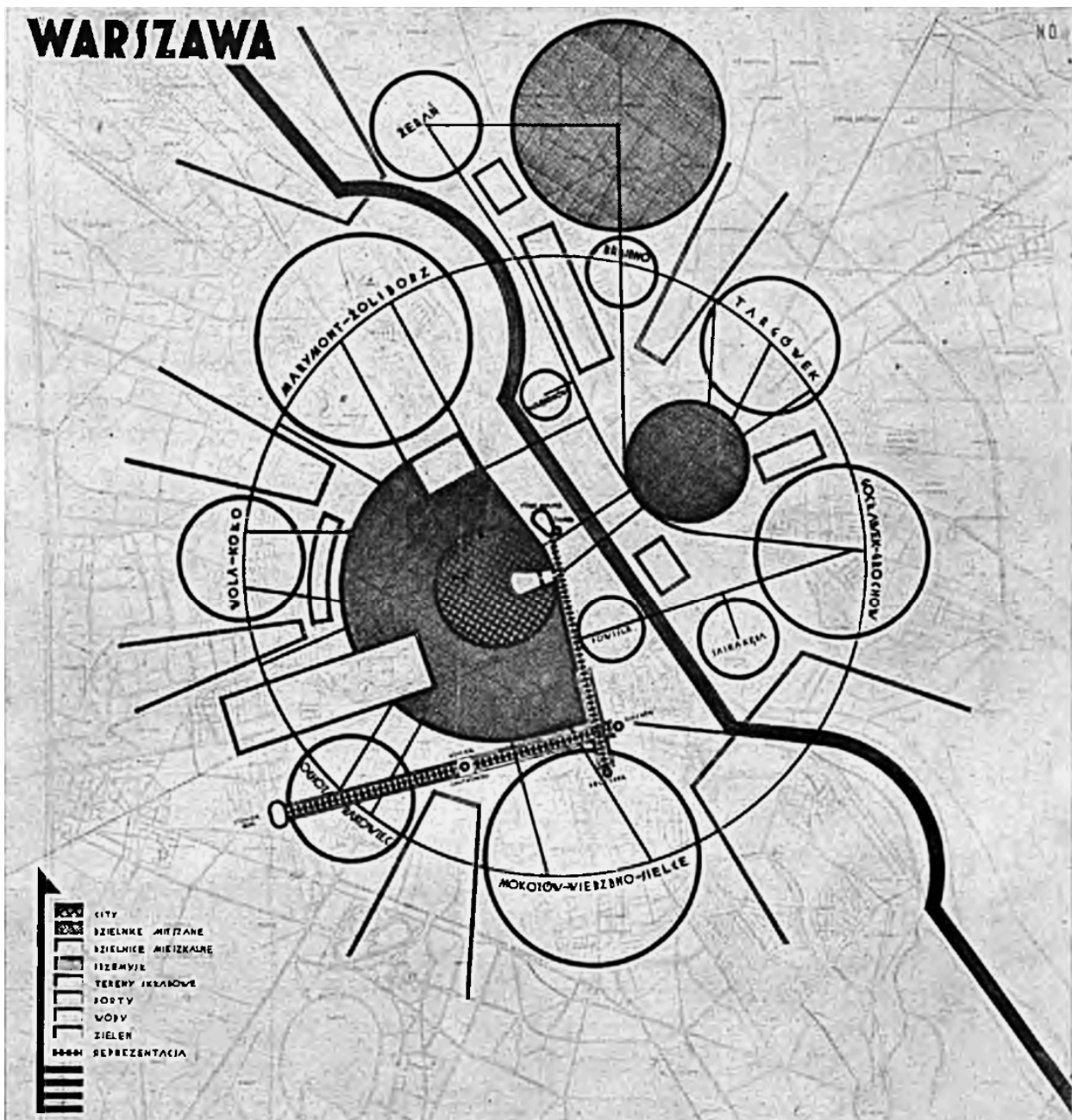

S.W.

\section{SCHEMAT PODZIALU DZIELNICOWECO}

Rys. 3. Uproszczony schemat rozwoju, stanowiący opracowanie uzupełniające do Planu Ogólnego Warszawy. Rysunek opracowany przez Stanisława Różańskiego. Reprodukcję opublikowano w czasopiśmie „Architektura i Budownictwo”, nr 11, 1928, s. 415

Fig. 3. Simplified development schematic, inlcuded as a supplement to the Warsaw Regulatory Plan. The drawing was made by Stanisław Różański. The reproduction was published in the magazine „Architektura i Budownictwo” nr 11, 1928, p. 415

Początki nowoczesnego myślenia planistycznego dostrzegalne są w opracowanym na przełomie lat 1926-1927 czwartym już planie regulacyjnym, uwzględniającym w zakresie znacznie bardziej rozbudowanym zagadnienia, takie jak kwestie komunikacyjne, budownictwo mieszkaniowe, zieleń miejska, 
użyteczność publiczna czy nawet otwarcia krajobrazowe, ze zwróceniem uwagi na uwarunkowania wpływające na rozwiązanie każdego $\mathrm{z}$ tych zagadnień i wpływem na całość organizmu miejskiego ${ }^{31}$. Pewne braki, zaistniałe w owej koncepcji korygowano w okresie późniejszym, w miarę rozwiązywania problemów natury prawnej i politycznej ${ }^{32}$. Plan (rys. 3.) należało dostosować do nowych warunków, co zajęło projektantom następny rok. Ostatecznie władze Warszawy plan przyjęły w 1929 roku, ministerstwo dopiero dwa lata później ${ }^{33}$.

\subsection{Wielki Lwów}

Podobnie jak Kraków, Lwów należał przez wiele do zaboru Austriackiego. Był jednak w owym okresie ośrodkiem większym. Ponadto był miastem rozwijającym się dość szybko, w okresie od 1869 do 1913 roku liczba ludności wzrosła z 87109 do 212080 osób $^{34}$. Drexler zauważył jednak, w oparciu o dane statystyczne, że zarówno gęstość zabudowy jak i liczba ludności, mieszkającej w ścisłym centrum miasta stopniowo malała, a przestrzeń centrum przyjęła formę okalającej stare miasto „gwiazdy”35. Prężne, postępowe i rozrastające się miasto wymagało wyznaczenia wyraźnego kierunku na przyszłość.

\section{Podsumowanie}

Okres przemian politycznych, społecznych i ustrojowych w Europie pierwszej połowy XX wieku to czas wyraźnego ożywienia w zakresie planowania przestrzennego. Projektanci zaczęli zauważać problemy, wcześniej nieistniejące, lub istniejące w znacznie mniejszym stopniu. Próbując odpowiedzieć na nie i sprostać wymaganiom skomplikowanych struktur miejskich, doskonale odpowiadali tezie, że urbanistyka to (między innymi) ,umiejętność budowania struktur podtrzymujących życie miejskie i sterowana ich rozwojem"36.

Choć idee Wielkich Miast nie są już tak popularne, jak chociażby w okresie międzywojennym, o poszerzenie ich granic niewielu walczy już z taką determinacją jak Juliusz Leo (Kraków powiększono ostatnio w 1986 r. ${ }^{37}$ ), a rozwój miast odbywa się bardziej organicznie niż w wieku XX, to wyzwania przed jakimi stają współcześni urbaniści, wykazują pewne podobieństwo do działań z tamtego okresu. Powszechne dążenie do podwyższenia jakości przestrzeni

\footnotetext{
${ }^{31}$ [13], s. 407-408.

32 Pominięto, między innymi kwestię granic stref zabudowy. Rozporządzenie Prezydenta Rzeczpospolitej z 16.02.1928 roku z jednej strony pozwoliło na rozwiązanie kwestii, z drugiej postawiło przed planistami kolejne wymagania.

33 [8], s. 56.

${ }^{34}$ [1], s. 14.

35 [11], s. 211.

36 [17], s. 32 .

${ }^{37}[6]$
} 
publicznych i prywatnych łączy epoki, dzielące tak wiele w kwestiach związanych z życiem społecznym, kulturowym czy nawet architektonicznych.

Opracowane w minionym wieku studia, przeprowadzone na potrzeby opracowania planów regulacyjnych, w wielu aspektach pozostają aktualne i poruszają wciąż dręczące przestrzenie miejskie bolączki. Dokuczliwy brak, odpowiedniej jakości, przestrzeni publicznej, zieleni, czy brak dbałości o walory widokowe miejskiej panoramy nie straciły na sile, a w wielu przypadkach skala ich oddziaływania poszerzyła się na kolejne aspekty życia w mieście. Najbardziej wartościowe rozwiązania zaproponowane przez dwudziestowiecznych planistów, choć często nigdy nie wprowadzone w życie pozostają aktualne i z powodzeniem implementowane mogą być, po odpowiednim przetworzeniu, do współczesnych koncepcji planistycznych.

Drexler postulował utworzenie Wielkiego Lwowa, argumentując tę potrzebę szeroką gamą czynników, w tym koniecznością podniesienia kultury gmin podmiejskich (traktując ją, zresztą jako powinność społeczeństwa miejskiego wobec ich mieszkańców) ${ }^{38}$. Idea ta miała się częściowo spełnić w 1930 roku, kiedy do Lwowa włączono część spośród wytypowanych gmin. Drexler jednocześnie krytykował szereg zjawisk zaistniałych we współczesnym sobie Lwowie, między innymi chaotyczny, jego zdaniem układ komunikacyjny w obrębie miasta. Pisał o nim słowami: „Skutkiem zupełnego zaniedbania w budowie, organicznie, lub choćby znośnie wiążących się ze sobą ulic okolnych we Lwowie, wynikają dla miasta i w miarę wzrostu ruchu powiększają się ustawicznie niedomagania komunikacyjne" ${ }^{39}$. Charakterystyczny dla jego poglądów jest wyraźnie perspektywiczny sposób myślenia. Problemy z komunikacją pomiędzy poszczególnymi częściami miasta były jedną z głównych osi drexlerowskiej koncepcji Lwowa. Jako wielką szansę dla ośrodka, postrzegał rozwój kolei i ewentualne powiązanie miasta z tym środkiem lokomocji i transportu.

\section{Literatura}

[1] Drexler I.: Wielki Lwów, Gmina Miasta Lwowa, Lwów, 1920

[2] Kapołka M.: Wybrane interwencje architektoniczne w obiektach modernistycznych wzdłuż Alei Trzech Wieszczów w Krakowie, [w:] Episteme, nr 33/2016, Kraków 2016, s. 59-71

[3] Klimas M., Lesiak-Przybył M., Sokół A.: Wielki Kraków - Rozszerzenie granic miasta w latach 1910-1915. Wybrane materiały ze zbiorów Archiwum Państwowego w Krakowie, Archiwum Państwowe w Krakowie, Kraków, 2010

[4] Kodym-Kozaczko G., Kozaczko M.: Plan ogólny zabudowania Poznania (19311939) na tle europejskiej teorii I praktyki budowy miast, [w:] Modernizm w Europie - modernism w Gdyni, Architektura lat międzywojennych i jej ochrona, red. Sołtysik M. J., Hirsch R., Gdynia, 2009, s. 105-114

\footnotetext{
38 [1], s. 63

${ }^{39}$ [11], s. 59, pisownia oryginalna
} 
[5] Kodym-Kozaczko G.: Rozwój przestrzenny w planowaniu urbanistycznym w latach 1900-1990, [w:] Architektura I urbanistyka Poznania w XX wieku, red. T. Jakimowicz, Poznań 2005, s.21-30

[6] Motak M.: Historia rozwoju urbanistycznego Krakowa w zarysie, Wydawnictwo Politechniki Krakowskiej, Kraków, 2012

[7] Mydel R.: Rozwój struktury przestrzennej miasta Krakowa, Ossolineum. Wrocław, 1979

[8] Nowakowski M.: Sto lat planowania przestrzennego polskich miast (1910-2010), Oficyna Naukowa, Warszawa, 2013

[9] Pajzderski S.: Rozbudowa miasta Poznania, [w:] Księga pamiątkowa Miasta Poznania, Magistrat Stołecznego Miasta Poznania, Poznań, 1929, s.507-511

[10] Paprocki A.: Konkurs na projekt regulacji i zabudowy m. Poznania, [w:] Architektura i Budownictwo, nr 1, 1932, s. 1-8

[11] Posatsky B.: Transformacje przestrzenne centrum Lwowa (plany i realizacje w ciągu XX i XXI wieku), [w:] Zeszyty Naukowe Politechniki Częstochowskiej 170, Budownictwo 20, Wydawnictwo Politechniki Częstochowskiej, Częstochowa 2015, s. $211-226$

[12] Różański S.: Plan ogólny Wielkiej Warszawy, [w:] Architektura i Budownictwo, nr 11, 1928, s. 410-415

[13] Rudnicki Cz.: Regulacja Warszawy w okresie wieku XIX i początku XX, [w:] Architektura i Budownictwo, nr 11, 1928, s. 404-409

[14] Seibert K.: Plan Wielkiego Krakowa, Wydawnictwo Literackie, Kraków, 1983

[15] Tołwiński T.: Urbanistyka Tom II, Budowa miasta współczesnego, Politechnika Warszawska, Warszawa, 1939

[16] Wielki Kraków, praca zbiorowa[w:] Architekt, nr 7, 1910

[17] Zuziak Z:: O tożsamości urbanistyki, Wydawnictwo Politechniki Krakowskiej, Kraków, 2008

\section{PLANS OF SPATIAL REGULATION OF POLISH GREATER CITIES IN THE FIRST HALF OF THE 20TH CENTURY AND CONTEMPORARY CONCEPTS OF URBAN DEVELOPMENT IN POLAND}

\section{S u m m a r y}

Although the roots of the concept of the so-called Polish greater cities go back to the nineteenth century, their realization and the greatest momentum with which they were systematically implemented was in the first half of the 20th century. The formation of the Second Polish Republic, after Poland regained its independence in 1918, became a turning point for local planning, and the new political situation was an excellent opportunity for the administrative apparatus to popularize the planning concepts and systematically bring them to life. The example of the competition for the design of the Greater Cracow, carried out in 1909, (determining the shape of the city in the interwar period) and the regulatory plan developed on its basis, began to propagate similar concepts for other cities, sometimes also on the basis of prestigious architectural competitions. 
In this context, the competition for the expansion and reconstruction of Lviv, announced on March $15^{\text {th }}$ 1921, and the o for the expansion and reconstruction of Lviv or the competition for the design and development of the city of Poznań, which was launched in 1930, should be mentioned. Those actions were not only of major planning value but also of a noticeable political and social aspect. The author describes individual concepts and some interesting competition entries, taking into account the conditions under which they were developed and the background on which these ideas were formulated. Observed analogies between historical and modern concepts have been pointed out and the main sources of their occurrence have been analyzed. Attention has also been paid to differences in spatial planning from the first half of the twentieth century and in a contemporary approach to similar issues. The cities located in the the current Polish lands and the historical borders were taken into account.

Keywords: Greater Kraków, Greater Warsaw, Project of regulation and development of Poznań, Regulatory plan, Interwar period, Spatial planning

Przestano do redakcji: 09.06.2017 r.

Przyjęto do druku: 01.09.2017 r. 